\section{3. 総}

括

オキノテッ゙ルモヅルの中央盤部からの油脂の脂肪酸成 分をメチルエステル分留法によって求めたとてろ, 飽和 酸は $\mathrm{C}_{14}$ 酸 $2.0 \%, \mathrm{C}_{16}$ 酸 $13.1 \%, \mathrm{C}_{18}$ および $\mathrm{C}_{18}$ 以 上の酸 $4.4 \%$, 不飽和酸は $\mathrm{C}_{16}$ 酸 $(-\mathrm{H}, 2.0) 11.1 \%$, $\mathrm{C}_{18}$ 酸 $(-\mathrm{H}, 3.9) 29.5 \%, \mathrm{C}_{20}$ 酸 $(-\mathrm{H}, 5.8) 21.9$ $\%, \mathrm{C}_{22}$ 酸 $(-\mathrm{H},>7.4) 18.0 \%$ になる。脂肪酸から バルミチン酸,オレイン酸および主にイワシ酸からなる と認められる高度不飽和酸を分離した。ステッン成分は 主に $\Delta^{5}$-ステリンで, その他に二重結合 2 個のステッン も多少存在するようである。 $\Delta^{5}$-ステリンとしては $\beta$-シ トステリンに相当するステリンを分離した。

クモヒトデの油脂の脂肪酸は水産動物油脂肪酸として はョウ素価 (94.1) が低い。ステリン成分はやはり主に \5ーステリンからなるようである。

本研究に要した費用の一部は服部報公会援助金から支 出した。
(昭和 29 年 11 月 5 日受理)

\section{（第 7 報） 本邦産貝類 11 種の 油脂の性状について}

著者は本研究第 5 報》において本邦産貝類 16 種の油 脂の性状について報告したが，その後さらに 11 種の貝 類を入手して油脂を抽出し，その性状をしらべたから， ここにその実験結果を報告する。今回試験した貝類は第 1 表渴げた通り腹足類 2 種, 完政带目 5 種, 原趴帯目 4 畽で，その内ツメタガイおよびリシヶタイラギの油脂 については第 5 焃にも記載したが, 今回はてれら 2 種の 貝類について肉部と内藏部とから別々に油脂を抽出し て, 油脂の性状を比較した。またオオノガイ, アサリ， カラスガイの油䏴については辻本，小楖両氏の研究2)3， セタシジミの油脂については堀, 細田両氏の研究(4)が発 表されている。

第 1 表 試 料一覽

\begin{tabular}{|c|c|c|c|c|c|c|c|c|c|c|c|}
\hline \multirow{2}{*}{$\begin{array}{l}\text { 試 } \\
\text { 料 } \\
\text { 番 } \\
\text { 号 }\end{array}$} & \multirow[t]{2}{*}{ 名 称 } & \multirow[t]{2}{*}{ 学 } & \multirow[t]{2}{*}{ 產 } & \multirow{2}{*}{$\begin{array}{l}\text { 入 手 } \\
\text { 年 月 }\end{array}$} & \multirow{2}{*}{ 個数 } & \multirow{2}{*}{$\begin{array}{c}\text { 総重量 } \\
(\mathrm{g})\end{array}$} & \multirow{2}{*}{$\begin{array}{c}\text { 剝 身 } \\
\text { 乾燥物 } \\
(\mathrm{g})\end{array}$} & \multicolumn{2}{|c|}{$\begin{array}{l}\text { エーテル } \\
\text { 抽出物 }\end{array}$} & \multicolumn{2}{|c|}{$\begin{array}{l}\text { アセトン } \\
\text { 可溶 部 }\end{array}$} \\
\hline & & & & & & & & $(g)$ & $(\%)$ & $(g)$ & $(\%$ \\
\hline \multirow[t]{2}{*}{1} & \multirow[t]{2}{*}{ ツメタガイ } & \multirow{2}{*}{ Neverita didyma } & \multirow[t]{2}{*}{ 鬼崎付近 } & \multirow[t]{2}{*}{29.3 .中 } & \multirow[t]{2}{*}{8} & \multirow[t]{2}{*}{1,185} & 豽 85 & 1.9 & 2.2 & 0.66 & 634.7 \\
\hline & & & & & & & 內㖑 80 & 5.7 & 7.1 & 3.6 & \\
\hline \multirow[t]{2}{*}{2} & \multirow[t]{2}{*}{$y= \pm$} & \multirow[t]{2}{*}{ Cipangopalu } & \multirow{2}{*}{$\begin{array}{l}\text { 長島方面 } \\
\text { の水田 }\end{array}$} & \multirow{2}{*}{ 29.3.下 } & \multirow{2}{*}{ 約 3,000} & \multirow[t]{2}{*}{011,800} & (肉 568 & 10.5 & 1.8 & 4.9 & 46.7 \\
\hline & & & & & & & 1内藏617 & 28.0 & 4.5 & 9.5 & \\
\hline 3 & オオノガイ & Mya arenaria japonica & 鍋田川川口 & 29.2 .中 & 36 & 3,710 & 185 & 9.5 & 5.1 & 8.2 & \\
\hline 4 & フジナミ & Sanguinolaria boeddinghausi & i鍋田川川口 & 29.2 .中 & 16 & \multirow{2}{*}{$\begin{array}{r}2,012 \\
735\end{array}$} & 140 & 7.3 & 5.2 & 4.0 & \\
\hline 5 & ア サ リ & Venerupis philippinarum & 福江付近 & 29.1.中 & 24 & & 33 & 1.5 & $\begin{array}{lll}5 & 4.7 & \end{array}$ & $0.7 \varepsilon$ & \\
\hline 6 & トリガイ & Cardium muticum & 鬼崎付近 & 29.3.中 & 13 & - & 55 & 3.3 & 6.0 & 2.0 & 61. \\
\hline 7 & セタシジミ & Corbicula sandai & 琵琶湖 & 28.12.下 & 654 & 5,400 & 164 & 27.2 & 16.6 & 16.8 & \\
\hline 8 & イケテウガイ & Hyriopsis schlegelii & 琵琶 湖 & 29.1 .中 & 5 & 2,895 & 152 & 9.4 & 6.2 & 6.4 & \\
\hline 9 & カラスガイ & Cristaria plicata spatiosa & 琵琶湖 & 29.1 .中 & 6 & 980 & 79 & 6.3 & 8.0 & 4.2 & 66. \\
\hline 10 & タイラギ & Pinnapectinata japonica & 鬼崎付近 & 29.2 .中 & 1 & 120 & 19 & 0.87 & $\begin{array}{ll}7 & 4.6\end{array}$ & 0.42 & 48.3 \\
\hline 11 & v & Pinn & & & 3 & 737 & $\{$ 肉 37 & 0.93 & 2.5 & 0.2 & 628.0 \\
\hline & & & 鬼崎付近 & & & & \{冈臟37 & 3.3 & 9.0 & 2.7 & \\
\hline
\end{tabular}

備考：本研究第 5 報にリシケタイラギの学名をPinnapectinata japonica と記載したが, 改訂増補日本動物図 鑑によるとタイラギに対してこの学名が与えられ，リシケタイラギの学名は Pinnapeclinata japonica (forma lischkeana) となっているから第 1 表にはそれぞれこの学名を記截した。第 1 表の產地は長島(三 重県), 琵琶湖をのぞきいずれも愛知県. 入手年月の小は中句，下は下旬. エーテル抽出物の\%は剥身乾 燥物に対する数字, アセトン可溶部の\%はエーテル抽出物に対する数字.

1) 外山, 高木, 本誌 75,1241 (1954).

2) 辻本, 小楖, 工化 37, 175 (1934).
3) 过本, 小㚹, 工化 37, 998 (1934).

4) 堸, 緇田, 本誌 74, 515 (1953). 


\section{実験およびその結果の考察}

\section{1. 試 料}

茜付の貝から設をのぞき，荆身を $80^{\circ} \mathrm{C}$ 以下で乾燥し 粉砕してェーテルで抽地した。エーテル抽归物（脂筫） は，これに 10 倍量のアセトンを加えて一旦還流加熱し てから冷却し常温で不溶部 (フォスファチド)をのぞき， アセトン可溶部（油脂）を収得した。ッメタガイ，マル タニシ，リシケタイラギの蚝身は肉部と内臟部とに分け て処理した。今回試験した貝類の名称, 学名, 産地, 入 手年月, 㸚身款燥物汃らのエーテル抽出物の収量, ア七 トン可溶部の収量などを一括して第 1 表に示した。

\section{2. 油脂の性状}

各試料の油脂（アセトン可溶部）の性状を示すと第 2 表の通りである。各油脂はいずれも著しく着色し, 色相 は各油脂でとに相違するが，おおむね暗赤橙色ないし暗 緑色で,常温では固体を析出してオオノガイ,トリガイ以
外のものは全体が㠜固して流動しない。

肉部と内臓部とに分けて採油した試料番号 (1)，(2), （11）についてみると，内藏部はエーテル抽出物（脂質） の収量が大で，油脂の性状を比較すると内臟油は肉油よ りもョウ素価が大である。また内䁍油は肉油よりも不ヶ 凶化物含量が小で，不ケン化物中のステリン含量も小で あるが，不ケン化物中のプロビタミンD含量は内㵴油の 方が大である。

今回試験した油脂の中でッメタガイ,オオノガイ，ノ サリ，セタシジミ，カラスガイ，リシケタイラギの油脂 の性状を既往の文献と比較すると第 3 表の通りで，同敇 の貝の油脂でもその性状が著しく相違する場合がある。 かような相違は供試油脂中に残存するフォスファチド含 量の相違にもよるものでないかと考えられるが，主とし て油脂の成分組成の相違に基づくものと考元られる。著 者 ${ }^{5}$ はすでに二，三の水産無瓷椎動物について，同種の 動物のステッン中に含まれる特定のステリンの含量に著 しい相違のあることを認めたが，同種の動物の漼脂の性

第 2 表 油脂 の 性 状

\begin{tabular}{|c|c|c|c|c|c|c|c|c|c|c|c|}
\hline 料 & & ע & ウ & 不公 & 脂 & 酸 & 不 & r & 化 & 物 & プロビ \\
\hline & 酸 価 & & & 化 物 & 中和価 & $\exists \quad$ ウ & $\begin{array}{l}x \\
y\end{array}$ & 粗 & $\bar{\tau}$ & ン & $\begin{array}{c}\text { タミン } \\
\text { D }\end{array}$ \\
\hline 号 & & 化 佂 & 素＼cjkstart価 & $(\%)$ & & 素 洒 & $(\%)$ & 収量(\%) & 敵点 $\left({ }^{\circ} \mathrm{C}\right)$ & |ョウ素価| & $(\%)$ \\
\hline \{肉 & 56.1 & 80.6 & 155.7 & 62.08 & - & - & 72.4 & - & $142 \sim 143$ & 95.1 & $4.0^{*}$ \\
\hline 11內臟 & 27.3 & 132.1 & 165.4 & 34.53 & 183.4 & 170.3 & 44.7 & - & $134 \sim 136$ & 113.4 & $7.9^{*}$ \\
\hline $2\{$ 肉 & 21.4 & 65.5 & 110.6 & 73.46 & 190.6 & 117.2 & 87.5 & 76 & $143 \sim 145$ & 68.9 & $2.7^{*}$ \\
\hline 內臟 & 44.7 & 109.2 & 117.0 & 47.87 & 191.4 & 124.1 & 79.0 & 64 & $136 \sim 139$ & 79.9 & $4.3^{*}$ \\
\hline 3 & 24.6 & 130.2 & 145.1 & 34.81 & 186.1 & 158.7 & 34.3 & - & $128 \sim 133$ & 99.0 & $1.5^{*}$ \\
\hline 4 & 25.6 & 152.9 & 141.0 & 27.13 & 185.9 & 164.3 & 52.8 & - & $133 \sim 135$ & 95.8 & $3.8^{*}$ \\
\hline 5 & 45.6 & 130.1 & 178.6 & 38.08 & - & 175.2 & 59.4 & 53 & $132 \sim 136$ & 122.4 & 9.9 \\
\hline 6 & 81.9 & 172.0 & 174.4 & 17.24 & 183.7 & 179.9 & 38.6 & - & $129 \sim 133$ & 116.2 & 6.2 \\
\hline 7 & 3.5 & 162.1 & 139.0 & 22.40 & 191.5 & 147.1 & 63.4 & 52 & $133 \sim 136$ & 118.1 & 9.3 \\
\hline 8 & 8.9 & 150.8 & 130.3 & 27.08 & 187.5 & 136.0 & 61.0 & 54 & $129 \sim 133$ & 92.9 & 3.1 \\
\hline 9 & 10.7 & 152.4 & 135.9 & 25.82 & 186.1 & 128.1 & - & 61 & $129 \sim 135$ & 115.9 & 15.5 \\
\hline 10 & 39.2 & 145.9 & 181.8 & 28.76 & - & 185.8 & 46.2 & - & $122 \sim 125$ & - & 6.0 \\
\hline$\{1$ 肉 & 39.3 & 90.3 & 162.9 & 60.05 & - & - & 78.1 & - & $135 \sim 136$ & 95.1 & $0.37 *$ \\
\hline '内㖑 & 39.8 & 158.9 & 189.2 & 23.84 & 182.4 & 180.5 & 40.1 . & - & $127 \sim 129$ & 150.3 & 15.3 \\
\hline
\end{tabular}

備考：ヨウ素価の测定は油脂怙よび脂肪酸に対してはWijis 法を用い, 不ヶン化物に対しては臭化ピリジン法 を用いた。ステリンはジギトニン法によって定量した。粗ステリンは不ケン化物を約 20 倍量のメタノー

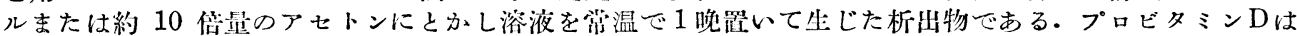
不ケン化物または粗ステリンのエタノール溶液について $282 \mathrm{~m} \mu, 277 \mathrm{~m} \mu, 290 \mathrm{~m} \mu$ に扎ける比吸光係数 を测定し，第 5 報に揭げた式から算出した。米印は不ヶン化物に対する％，その他は粗ステリンに対す る\% な゙ある・ツメタガイ闪油とリシケタイラギ內臟油の不ケン化物は $260 \mathrm{~m} \mu$ 付近にも明磪な極大吸収 を示した。数種の試料油の脂肪酸について鉛垍エタノール法により国体酸を定最した絬果は，マルタニシ 肉油 $28.8 \%$ (ヨウ菜価 16.2)，マルタ=シ內䏼油 $29.2 \%$ (ヨウ素価 14.9 )，イケテウガイ油 $25.4 \%$ (ヨウ素伢 11.5)，カラスガイ油 $24.1 \%$ ( ヨウ素価 16.1) であった.

5) Y. Toyama, T. Tanaka, Bull. Chem. Soc. Japan 26, 497 (1953); 27, 264 (1954); Y. Toyama, T. Takagi, ibid. 27, 421 (1954). 
第 3 表 同種油脂の性状の比較

\begin{tabular}{|c|c|c|c|c|c|c|c|c|}
\hline \multirow{2}{*}{ 油 } & \multirow{2}{*}{ ン 化 価 } & \multirow{2}{*}{$\exists$} & \multirow{2}{*}{ ウ素 価 } & \multirow{2}{*}{$\begin{array}{c}\text { 不ヶン化物 } \\
(\%)\end{array}$} & \multicolumn{2}{|r|}{ 脂 } & \multicolumn{2}{|c|}{ j 酸 } \\
\hline & & & & & 中 & 和 価 & & ウ素価 \\
\hline ツメタガ $\{$ 第 1 表內酿油 & 132.1 & & 165.4 & 34.53 & & 183.4 & & 170.3 \\
\hline $1 \quad$ 外山, 高末 $^{12}$ & 163.5 & & 147.0 & 29.17 & & 186.9 & & 140.4 \\
\hline オオノガ 第 1 表 & 130.2 & & 145.1 & 34.81 & & 186.1 & & 158.7 \\
\hline $1 \quad$ 辻本, 小柳 ${ }^{3)}$ & - & & - & - & & - & & $161.5^{*}$ \\
\hline アサリ（第 1 表 & 130.1 & & 178.6 & 38.08 & & - & & 175.2 \\
\hline 过本, 小柳2) & 103.2 & & 188.7 & 45.7 & & 192.0 & & 180.0 \\
\hline セタシジ (第 1 表 & 162.1 & & 139.0 & 22.40 & & 191.5 & & 147.1 \\
\hline ミ $\quad$ 堀, 細田 $\left.^{4}\right)$ & 181.1 & & 144.2 & $27.5^{*}$ & & 197.2 & & 142.9 \\
\hline カラスガ 筑 1 表 & 152.4 & & 135.9 & 25.82 & & 186.1 & & 128.1 \\
\hline $1 \quad$ 辻本, 小柳2) & 135.0 & & 167.9 & 25.9 & & 196.3 & & 162.3 \\
\hline リシチタ $\{$ 第 1 表內臟油 & 158.9 & & 189.2 & 23.84 & & 182.4 & & 180.5 \\
\hline イラギ 【外山, 高末 ${ }^{1)}$ & 163.7 & & 196.8 & 29.72 & & - & & 168.0 \\
\hline
\end{tabular}

備考：1)〜4）は交献前出，*×ーテル抽出物について湘定.

状, 成分組成にかような著しい相違のあるととは注目す べき事奉で，一般に魚油は植物油にくらべると同種の油 の性状にかなり著しい相違を示すととがあるが，水㦃然 脊椎動物油脂になるとての傾问がさらに一層影著である と認められる。

\section{3. 数種の試料油のステリン成分}

マルタニシ肉油の不ケン化物をアセトンから再結晶し て得た析正物を酢化して融点 $121^{\circ} \sim 125^{\circ} \mathrm{C}$ ，ケン化価 131.5，ヨウ素仙 76.7 の酶酸エステルを得た。てれを さらに4 回坶結晶したものは融点 $130^{\circ} \sim 131^{\circ} \mathrm{C}$ 、ヨウ素 洒 86.5 , プロビタミン D 含量 $1.5 \%$ を示した。マル タニシ内䁍油の不ケン化物汃ら同様にして融点 $123^{\circ}$ $125^{\circ} \mathrm{C}$, ケン化侕 130.4 , ヨウ素価 $79.9,[\alpha]_{\mathrm{D}}^{28}=-41.4^{\circ}$ の䣷睃エステルを得た。てれをさらに再結晶すると融点 は上梨し 4 酋再結晶後のものは融点 $136^{\circ} \sim 137^{\circ} \mathrm{C}, \exists$ ウ 菜埏 84.4 ，プロビタミンD含量 $2.4 \%$ ，乙れをケン化 して得た遊離ステリンは融点 $137^{\circ} \sim 139^{\circ} \mathrm{C}$ 走示した。 てれらの実験結果によるとマルタニシ油はつぎに記載す るセタシジミ油, イケテウガイ油，カラスガイ油と異な りそそのステリンは酶酸エステルにして再結晶するとプ ロビタミンD含量は減少する。ヨウ素俩加みて, マル タニシ油のステリンは $F_{1}$ ーステリンを多く含むものと認 められる。

セタシジミ油の不ヶン化物をメタノールから再結晶し たもの在酢化して融点 $118^{\circ} \sim 120^{\circ} \mathrm{C}$, ケン化亚 130.1 , $[\alpha]_{D}^{28}=-43.4^{\circ}$ の酢酸エステルを得た。とれをさらに アセトンから数回再結晶したものは融点 $149^{\circ} \sim 151^{\circ} \mathrm{C}$,
プロビタミンD含量 $40.9 \%$ である。またアセトン母液 から回収した醀酸エステルをエーテル溶液で臭素源加す るとポリンェラステリン醡酸エステル四臭化物と思われ る融点 $186^{\circ} \mathrm{C} の$ エーテル不溶性实化物を得た。てれを 脱舁素して得た生成物をエタノールから再結晶したもの は副点 $145^{\circ} \sim 146^{\circ} \mathrm{C}$ でポリフェラステリン酰酸エステ ルと混动して融点降下を示さない。

イケテウガイ油の不ケン化物をメタノールから再結晶 したもの党䣫化して融点 $116^{\circ} \sim 119^{\circ} \mathrm{C}$, ケン化洒 130.1 , $[\boldsymbol{\alpha}]_{\mathrm{D}}^{28}=-40.5^{\circ}$ の酶酸エステルを得た。乙れをさらに アセトンから 3 回再結晶したものは融点 $139^{\circ} \sim 141^{\circ} \mathrm{C}$, プロビタミンD含量 $6.6 \%$ である。アセトン母液から

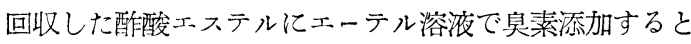
融点 $175^{\circ} \mathrm{C}$ のエーテル不溶性莫化物を得た。てれをク ロロホルム・メタノールから再結晶して精製したものは 融点 $187^{\circ} \mathrm{C}$ を示し，ポリフェラステリン酶酸エステル 四臭化物と思われる。

カラスガイ油の不ヶン化物をメタノールから再結晶し たものを酢化して蛆点 $116^{\circ} \sim 119^{\circ} \mathrm{C}$ ，ヶン化侕 129.8， $[\alpha]_{\mathrm{D}}^{25}=-38.9^{\circ}$ の醀酸エステルを得た。これをメタ， ール抢よびアセトンから 4 回再結晶したものは融点 $141^{\circ}$ 〜 $143^{\circ} \mathrm{C}$ ，プロビタミン D含量 $19.5 \%$ である。

\section{4. 数種の試料油の高度不飽和酸}

数種の試料油の脂肪酸を哇素気流中， $21 \%$ 水酸化カ

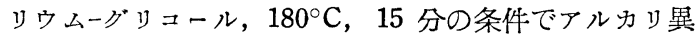
性化し, 異性化生成物をエタノール溶液にしてそれぞれ $235,270,316,348,376 \mathrm{~m} \mu$ における比吸光係数を測 
第 4 表 アルカリ異性化脂肺酸の紫外部吸収スペクトルから求めた高度不䳌和酸含量

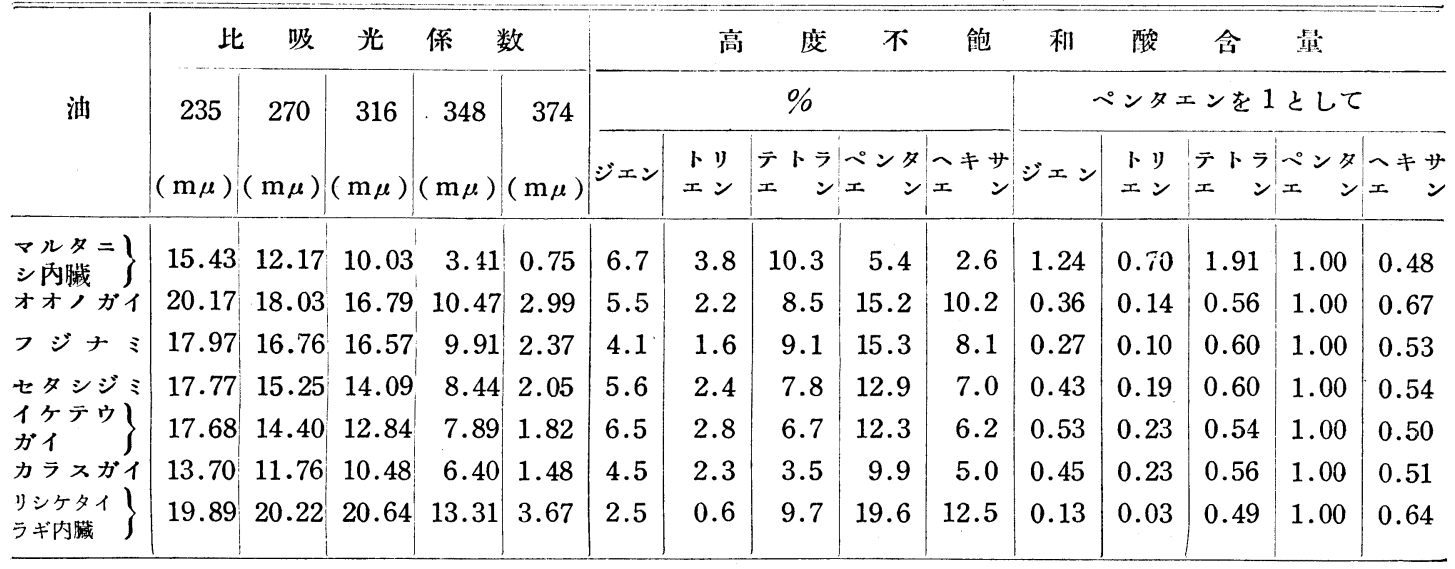

定し, Hammond, Lundberg ${ }^{6)}$ の式を䐪いて脂肪酸中 の高度不飽和酸含㟟を算出した。ただし Hammond, Lundberg は上記波長の代りにそれぞれ 233，268， 315，346，374 m $\mu$ を採肘しているが，著者の测定では 上記波長にそれぞれ極大吸収を示したから上記の波長を 採用した。笑踰結果を示すと第 4 表の通りである。

Hammond, Lundbergの式が本実験の埸合に適用し て正しい結果を与えるかどうかは，今後なお検傠を要す る。またアルカリ異性化条件のわずかの相違によって異 性化生成物の紫外部吸収スペクトルは著しく影響を受け るから第 4 表に揭げた高度不飽和酸含量も真の值とかな り相違するかもしれないが，各種高度不飽和睃の含有制 合をみると, マルタニシ油をのぞいてペンタエン酸が最 大, トリエン酸が最小で, ペンタエン酸 1 亿対しトリエ ン酸 $0.03 \sim 0.23$, ジェン酸 $0.17 〜 0.53$, テトラエン酸 0.49〜0.60，一キ开エン酸 0.50〜0.67 であるお்，マル タニシ油だけは例外でテトラエン酸が最大, ジェン酸, ペソタエン酸, トリエン酸, 入キサエン酸の順である。

\section{総括}

1. 本邦産貝類 11 種から油脂を抽出して, その一般 性状をしらべた。

2. ツメタガイ, マルタニシ，リシケタイラギについ て肉部と内臟部を比較すると，内臓部はエーテル抽出物 (脂質) の収量が大である。また油脂（アセトン可溶部） の性状を比較すると内臓油は肉油よりもヨウ素価が大, 不ヶン化物含量が小である。不ケン化物は内臓油の方が ステリン含量小であるがプロビタミン $\mathrm{D}$ 含量大である。

6) E. G. Hammond, W. O. Lundberg, J. Am. Oil Chemists' Soc. 30, 433 (1953).
3. 数種の試料油の性状を既任の文献と比較した結果 によると, 同じ種類の貝の油脂でもその性状が著しく相 違する埸合があって，ての点は魚油の㙋合よりもさらに 一詹顕著である。

4. 七タシジミ油, イケテウガイ油, カラスガイ油か らのステリン酢酸エステルは再結晶によってプロビタミ ソDが濃縮されたが，マルタニシ油からのステリン醀酸 エステルは再結晶によってプロビタミンD念量が減少し た。

5. マルタニシ，オオノガイ，ソジミ、セタシジミ， イケテウガイ, リシケタイラギの油脂の䏴䏳酸のアルカ り晎性化生成物について紫外部吸収スペクトルを测定 し, 各種の高度不飽和含量を求めてみると, マルタ二シ 油ではテトラエン酸がペンタエン酸よりも多いが，その 他の油ではペンタエン酸がテトラエン酸およびへキサエ ン酸よりも多い。

本砳労は文部省機関砳究の一部である。また本砳究に 要した費用の一部は服部報公会援助金から妾出した。

(昭和 29 年 11 月 8 日受理)

\section{（第 8 報） イシコ，ヤツデヒトデ， ウミシダの油脂，ことにその ステリンについて}

掲題の梀皮動物 3 種のうち，イシュの不ケン化物成分 としてバチルアルコールが存在するてとはすでに発表 されているが，今回は不ヶン化物成分としてバチルアル コール以外に比較的少量存在するステリン成分を検索 し, その主要部として $\Delta^{3}$ ンレステノールを確認した。

1) 松本, 矢泉, 外山, 本誌 64, 1203 (1943). 